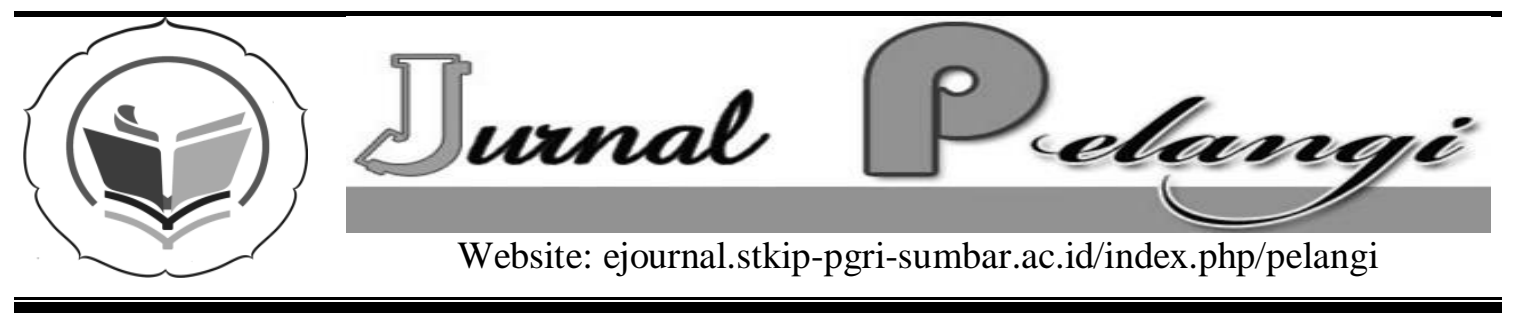

\title{
UPAYA PENINGKATAN PEMAHAMAN RUANG SISWA SMP MELALUI STRATEGI EVERYONE IS A TEACHER HERE
}

\author{
Sofia Edriati, Mulia Suryani, dan Winda Rahma Putri \\ STKIP PGRI sumatera Barat \\ sofiaedriati81@gmail.com
}

\section{INFO ARTIKEL}

Diterima:

1 September 2016

Direview:

27 Oktober 2016

Disetujui:

28 Desember 2016

Kata Kunci:

Pemahaman Ruang, Everyone is a Teacher Here

\section{Keywords:}

Understanding of Space, Everyone is a Teacher Here

\begin{abstract}
Abstrak
Penelitian ini bertujuan untuk mengetahui apakah pemahaman ruang siswa dengan menerapkan strategi Everyone is a Teacher Here lebih baik daripada pemahaman ruang siswa dengan menerapkan pembelajaran konvensional. Jenis penelitian ini adalah kuasi eksperimen, dengan rancangan penelitian random terhadap subjek. Populasi penelitian adalah siswa kelas VIII SMPN X kota Padang. Pengambilan sampel menggunakan teknik cluster random sampling. Instrumen yang digunakan adalah lembar tes berbentuk uraian yang telah diujicobakan pada siswa dengan karakteristik yang sama dengan populasi penelitian. Teknik analisis data tes akhir menggunakan uji t satu pihak. Hasil penelitian menunjukkan bahwa pemahaman ruang siswa dalam pembelajaran matematika yang menerapkan strategi pembelajaran aktif tipe Everyone is a Teacher Here (ETH) lebih baik daripada pemahaman ruang siswa yang menggunakan pembelajaran konvensional.

Abstract

This study aims to determine whether the understanding of space by implementing the strategy Everyone is a Teacher Here is better than the understanding of space by applying conventional learning. This research type is quasi experiment, with research design is random subject. The population is students of class VIII SMPN X Padang. Sampling using cluster random sampling technique. The instrument used is a test that has been piloted on students with characteristics similar to the study population. The final test data analysis technique uses one-party $t$ test. The result of the research shows that the understanding of student space in the mathematics learning that apply the active learning strategy of Everyone is a Teacher Here (ETH) type is better than the understanding of the student space using conventional learning.
\end{abstract}




\section{PENDAHULUAN}

Menurut Sardjana (2008: 1) "geometri merupakan cabang yang mempelajari titik, garis, bidang dan benda-benda ruang serta sifat-sifatnya, Peukuran-ukurannya dan hubungannya satu sama lain. Jadi, geometri dapat dipandang sebagai pengetahuan yang mempelajari tentang ruang.

Materi geometri berkaitan dengan pengukuran. Dalam kehidupan seharihari banyak dijumpai hal-hal yang berkaitan dengan pengukuran, karena pengukuran merupakan jembatan yang menghubungkan areal matematika sekolah dengan geometri. Pengukuran merupakan salah satu bentuk aplikasi matematika yang sangat luas, misalnya untuk mengumpulkan dan mencatat data-data seperti volume, luas permukaan, kecepatan, besaran dan satuan pokok.

Kemampuan pemahaman matematika merupakan suatu tujuan penting dalam proses pembelajaran, dengan memahami materi siswa dapat lebih mengerti akan konsep materi pelajaran itu sendiri.Pemahaman berarti proses, perbuatan, cara memahami atau menanamkan. Pemahaman ruang merupakan salah satu tujuan dari pembelajaran geometri. Menurut Nemeth dalam syahputra (2007: 123) "kemampuan pemahaman ruang merupakan proses dimana memahami dan menanamkan kemampuan spasial yang dibutuhkan pada ilmu-ilmu teknik dan matematika khususnya geometri".

Kemampuan spasial merupakan satu konsep dalam berpikir spasial. Linn dan Petersen dalam Syahputra (National Academy of Science, 2006:44) mengelompokkan kemampuan spasial ke dalam tiga indikator yaitu: (1) persepsi spasial adalah kemampuan spasial yang membutuhkan letak horizontal serta letak vertikal, (2) rotasi mental adalah kemampuan untuk menyesuaikan diri dalam suatu ruang, (3) visualisasi visual adalah kemampuan untuk menunjukkan aturan perubahan atau perpindahan penyusunannya dari suatu susunan.

Berdasarkan hasil observasi ditemukan bahwa pemahaman ruang siswa masih rendah. Siswa belum mampu menggunakan teorema pythagoras untuk menghitung panjang suatu sisi segitiga siku-siku. Siswa kurang memahami materi geometri yang berkaitan dengan objek atau gambar pada bangun geometri sehingga siswa tidak bisa menyelesaikan soal yang diberikan dengan baik dan benar. Siswa kurang mau bertanya kepada guru terhadap materi ataupun soal-soal yang tidak dipahaminya. Siswa tidak terbiasa bertanya sehingga tidak memiliki keberanian untuk bertanya. Salah satu upaya untuk mengatasi permasalahan yang ada dibutuhkan suatu variasi strategi pembelajaran yang dapat membantu siswa dalam memahami materi khususnya pada pemahaman ruang. Salah satu alternatif yang dapat mengatasi masalah di atas adalah strategi pembelajaran Aktif tipe Everyone is a Teacher Here (ETH).

Everyone is a Teacher Here (ETH) sangat baik digunakan pada siswa yang kurang berani mengungkapkan pertanyaan, keinginan dan harapanharapan melalui percakapan. Pada penerapan ETH guru bisa menggunakan kartu indeks untuk mengetahui hal-hal yang tidak dipahami ataupun hal-hal yang dinginkan siswa. Hal ini diperkuat oleh Silberman (2014: 183 ) yang menyatakan bahwa "strategi Everyone is a Teacher Here (ETH) ini sangat tepat untuk mendapatkan partisipasi kelas secara keseluruhan dan secara individual. Karena strategi ini memberikan kesempatan kepada setiap siswa untuk berperan sebagai guru bagi teman-temannya". 
Menurut Silberman (2014: 183) beberapa prosedur pembelajaran ETH sebagai berikut:

1) Bagikan kartu indeks kepada setiap peserta didik. Mintalah para peserta menulis sebuah pertanyaan yang mereka miliki tentang materi pelajaran yang sedang dipelajari di dalam kelas atau topik khusus yang akan mereka diskusikan di kelas.

2) Kumpulkan kartu, kocok dan bagikan satu pada setiap siswa. Mintalah siswa membaca diam-diam pertanyaan atau topik pada kartu dan pikirkan satu jawaban.

3) Panggillah sukarelawan yang akan membaca dengan keras kartu yang mereka dapat dan memberi respons.

4) Setelah diberi respons, mintalah yang lain di dalam kelas untuk menambahakan apa yang telah disumbang sukarelawan.

5) Lanjutkan selama masih ada sukarelawan.

Berdasarkan uraian di atas, penelitian ini bertujuan untuk mengetahu apakah pemahaman ruang siswa yang menggunakan strategi ETH lebih baik daripada siswa yang menggunakan pembelajaran konvensional.

\section{METODE PENELITIAN}

Penelitian ini menggunakan dua kelas sampel yaitu kelas eksperimen dan kelas kontrol. Pada penelitian ini perlakuan yang diberikan pada kelas eksperimen dengan menggunakan Strategi Aktif Tipe Everyone is a Teacher Here (ETH) sedangkan pada kelas kontrol menerapkan pembelajaran konvensional. Dalam pelaksanaan penelitian ini, kedua kelas sampel diberi tes akhir untuk melihat pemahaman ruang kedua kelas. Rancangan penelitian yang digunakan adalah random terhadap subjek.
Populasi dalam penelitian ini adalah seluruh siswa kelas VIII SMPN X Kota Padang. Karena populasi dalam penelitian ini berdistribusi normal dan memiliki variansi yang homogen maka pengambilan sampel bisa dilakukan secara acak. Kelas yang terambil pertama adalah kelas eksperimen dan kelas yang terambil kedua adalah kelas kontrol.

Instrumen yang digunakan dalam penelitian ini adalah tes akhir yang berupa soal esai (uraian). Analisis data yang digunakan adalah uji t. Menurut Sudjana (2005: 239) adalah:

$$
t=\frac{\bar{x}_{1}-\bar{x}_{2}}{S \sqrt{\frac{1}{n_{1}}+\frac{1}{n_{2}}}}
$$

Dengan:

$$
s^{2}=\frac{\left(n_{1}-1\right) s_{1}{ }^{2}+\left(n_{2}-1\right) s_{2}{ }^{2}}{n_{1}+n_{2}-2}
$$

$\bar{x}_{1}=$ nilai rata-rata pemahaman ruang siswa kelas eksperimen

$\bar{x}_{2}=$ nilai rata-rata pemahaman ruang siswa kelas kontrol

$\mathrm{n}_{1}=$ jumlah siswa kelas eksperime

$\mathrm{n}_{2}=$ jumlah siswa kelas kontrol

$\mathrm{s}_{1}{ }^{2}=$ variansi kelas eksperimen

$\mathrm{s}_{2}{ }^{2}=$ variansi kelas kontrol

$\mathrm{s} 2=$ variansi total

$\mathrm{S}$ = simpangan baku kedua kelas

Kriteria pengujian adalah Terima $\mathrm{H}_{0}$ jika $t_{\text {hitung }}<t_{\text {tabel (1- } \alpha)}$ dengan derajat kebebasan $(\mathrm{dk})=\left(n_{1}+n_{2}-2\right)$, tolak $\mathrm{H}_{0}$ jika $\mathrm{t}$ mempunyai harga yang lain.

\section{HASIL DAN PEMBAHASAN}

Berdasarkan perhitungan terhadap hasil tes akhir siswa, didapat nilai ratarata $(\bar{x})$, simpangan baku (s), skor tertinggi $\left(x_{\max }\right)$ dan skor terendah $\left(x_{\text {min }}\right)$ tes akhir kelas sampel sesuai dengan tabel 1. 
Tabel 1. Perhitungan Rata-rata $(\bar{x})$, Simpangan baku $(S)$, Skor Tertinggi $\quad\left(x_{\text {maks }}\right)$ dan Skor Terendah $\left(x_{\min }\right)$ Pada Kelas Sampel

\begin{tabular}{ccccc}
\hline Kelas Sampel & $\bar{x}$ & $S$ & $x_{\text {maks }}$ & $x_{\min }$ \\
\hline Eksperimen & 77,325 & 12,565 & 100 & 52,67 \\
Kontrol & 71,262 & 17,061 & 96,77 & 33,33 \\
\hline
\end{tabular}

Berdasarkan uji t satu pihak yang dilakukan diperoleh $t_{\text {hitung }}=$ 6,33 dengan $t_{\text {tabel }}=1.6$, karena $t_{\text {hitung }}>t_{\text {tabel }}$, dapat disimpulkan bahwa pemahaman ruang siswa dengan menerapkan strategi pembelajaran aktif tipe Everyone is a Teacher Here lebih baik daripada pemahaman ruang siswa dengan pembelajaran konvensional.

Proses pembelajaran pada kelas eksperimen sesuai dengan tahap-tahap pelaksanaan strategi pembelajaran Aktif tipe Everyone is a Teacher. Pada pembukaan pelajaran guru mengecek kehadiran dan kesiapan siswa sebelum memulai pembelajaran, menciptakan suasana yang kondusif, dan guru memberikan motivasi serta menyampaikan tujuan pembelajaran yang akan dicapai oleh siswa. Guru menjelaskan langkah pembelajaran Everyone is a Teacher Here dan membagi siswa dalam beberapa kelompok.

Kegiatan inti pada pelaksanaan strategi pembelajaran aktif tipe Everyone is a Teacher Here diawali dengan guru membagikan kartu indeks untuk masingmasing siswa, siswa diberi kesempatan untuk mengamati dan memahami materi pada buku teks, kemudian masingmasing siswa diminta untuk membuat pertanyaan pada kartu indeks yang telah diberikan guru. Selanjutnya siswa dibagi menjadi beberapa kelompok. Kartu indeks yang berisi pertanyaan dikumpulkan kembali kepada guru berdasarkan kelompok, kemudian kartu tersebut dikocok dan diberikan kepada masing-masing siswa dengan syarat tidak ada siswa yang menerima pertanyaan yang dia buat sendiri. Siswa diminta membaca dan mendiskusikan masalah tersebut dengan teman sekelompoknya. Terakhir guru memanggil salah satu anggota kelompok sebagai perwakilan kelompok untuk maju kedepan kelas untuk menjelaskan jawaban dari pertanyaan yang telah dijawab.

Pertemuan pertama beberapa siswa masih belum mengerti dengan model pembelajaran yang dilaksanakan, sehingga guru menjelaskan kembali langkah pembelajaran tipe Everyone is a Teacher Here. Siswa kurang serius dan masih ragu untuk mengisi kartu indeks yang diberikan guru. Selain itu, masih terjadi keributan saat siswa diminta untuk duduk berkelompok dan siswa masih belum sepenuhnya berdiskusi dalam kelompok sehingga masih banyak jawaban dalam kartu indeks yang salah. Adapun bentuk kartu indeks pertemuan I dapat dilihat pada Gambar 1 .

Gambar 1 memperlihatkan bahwa masih ada soal yang belum bisa dijawab oleh siswa dengan baik dan benar, seperti soal diatas siswa belum bisa membedakan antara diagonal bidang dengan bidang diagonal.

Pertemuan kedua proses pembelajaran masih sama dengan pertemuan pertama,namun siswa sudah sedikit mengerti dengan langkah pembelajaran yang dilaksanakan. Pada pertemuan kedua ini siswa sudah mulai serius membuat pertanyaan dan menjawab soal pada kartu indeks, siswa juga mulai mau berdiskusi dengan teman sekelompoknya, saat siswa disuruh duduk berkelompok masih terjadi sedikit 
keributan dan beberapa pertanyaan pada kartu indeks masih dijawab kurang lengkap. Mengatasi hal itu guru memberikan arahan kepada siswa. Bentuk kartu indeks pertemuan II dapat dilihat pada Gambar 2.

Gambar 2 terlihat bahwa siswa sudah bisa menjawab soal yang diberikan tetapi masih terdapat kekurangan siswa dalam menjawab, seperti pada soal diatas siswa sudah dapat membuat jaring-jaring prisma dan hanya saja ada beberapa bagian yang tidak bisa diselesaikan oleh siswa ini dengan baik sehingga perolehan skornya berkurang.

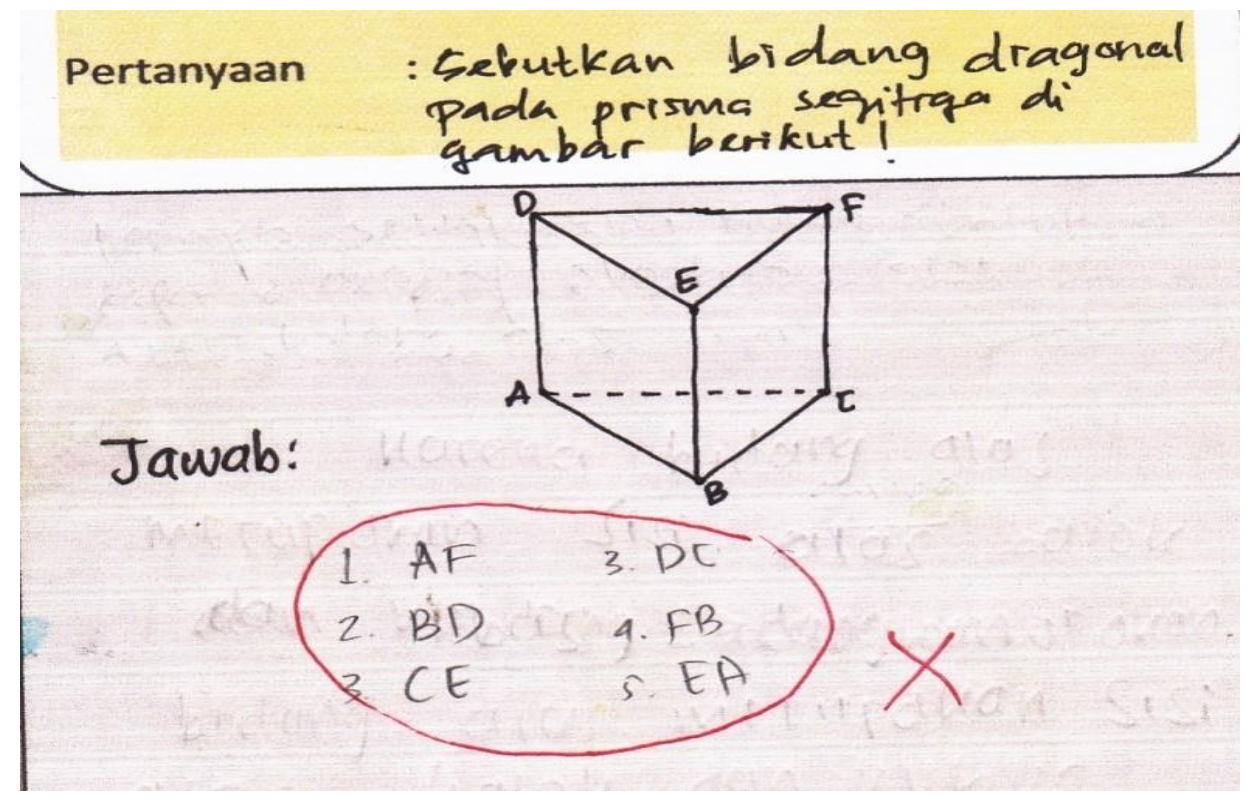

Gambar 1. Contoh hasil jawaban siswa dikartu indeks pada pertemuan 1

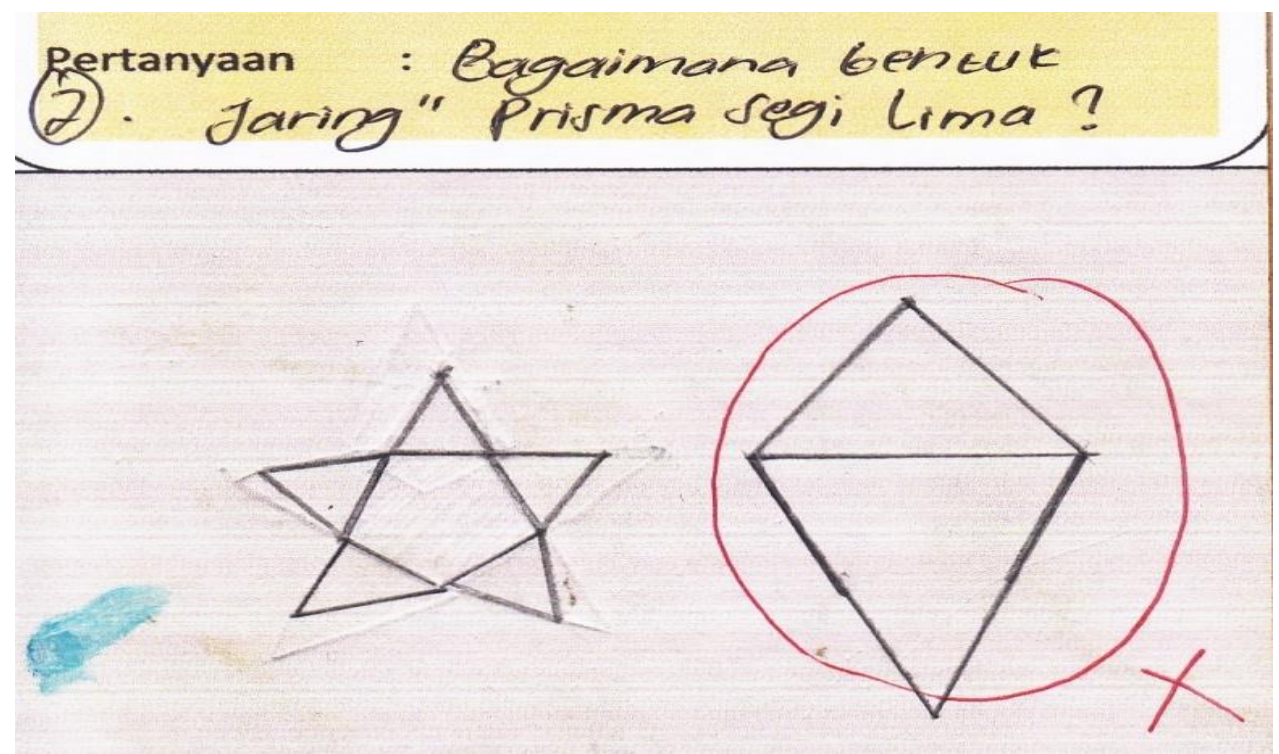

Gambar 2. Contoh hasil jawaban siswa pertemuan II 
Pertemuan ketiga dan keempat siswa sudah terbiasa dengan strategi ETH. Siswa tidak canggung lagi duduk berkelompok dan diskusi berjalan dengan lancar. Jawaban untuk pertanyaan pada kartu indeks sudah banyak yang benar. Bentuk hasil jawaban siswa pada pertemuan ketiga dan keempat dapat dilihat pada Gambar 3. Pada Gambar 3 terlihat bahwa soal yang dikerjakan siswa sudah terjawab dengan baik dan benar walaupun masih

terdapat sedikit kekurangan pada kesimpulan akhir dari soal.

Gambar 4 terlihat bahwa siswa sudah mampu mendiskusikan dan mengerjakan soal yang diberikan, sehingga jawaban pada kartu indeks yang sudah didiskusikan dengan kelompoknya sudah terjawab dengan baik dan benar. Siswa sudah serius dalam mengerjakan soal yang diberikan oleh guru.

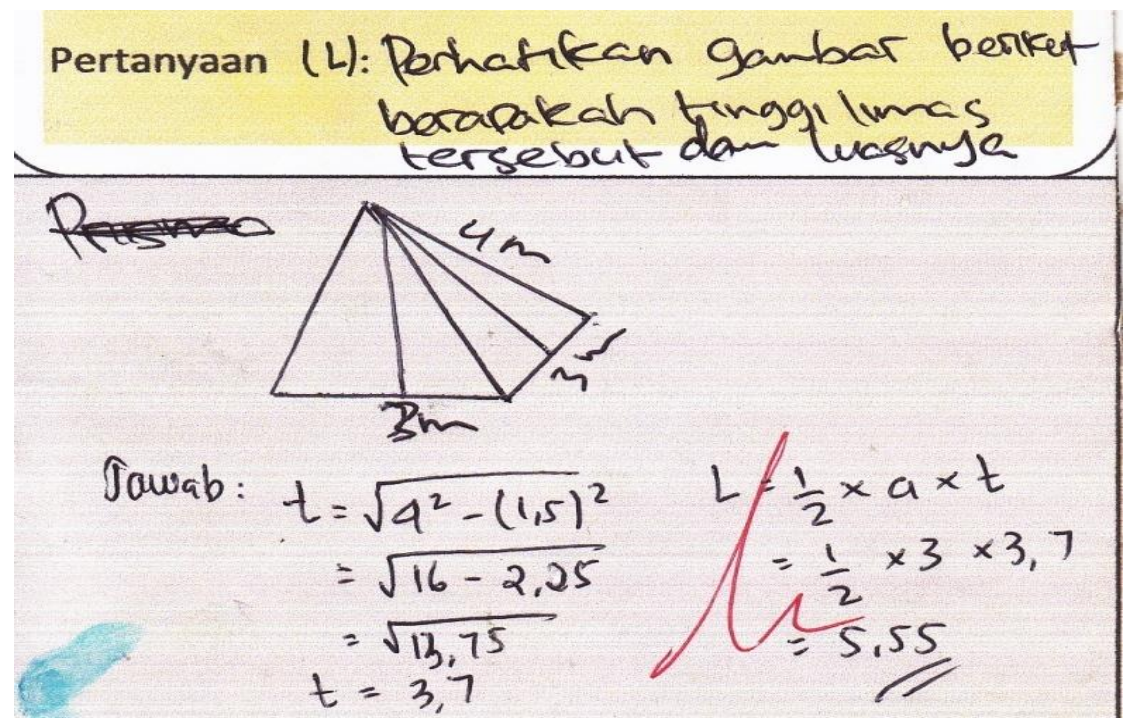

Gambar 3. Contoh hasil jawaban siswa 1 pertemuan III

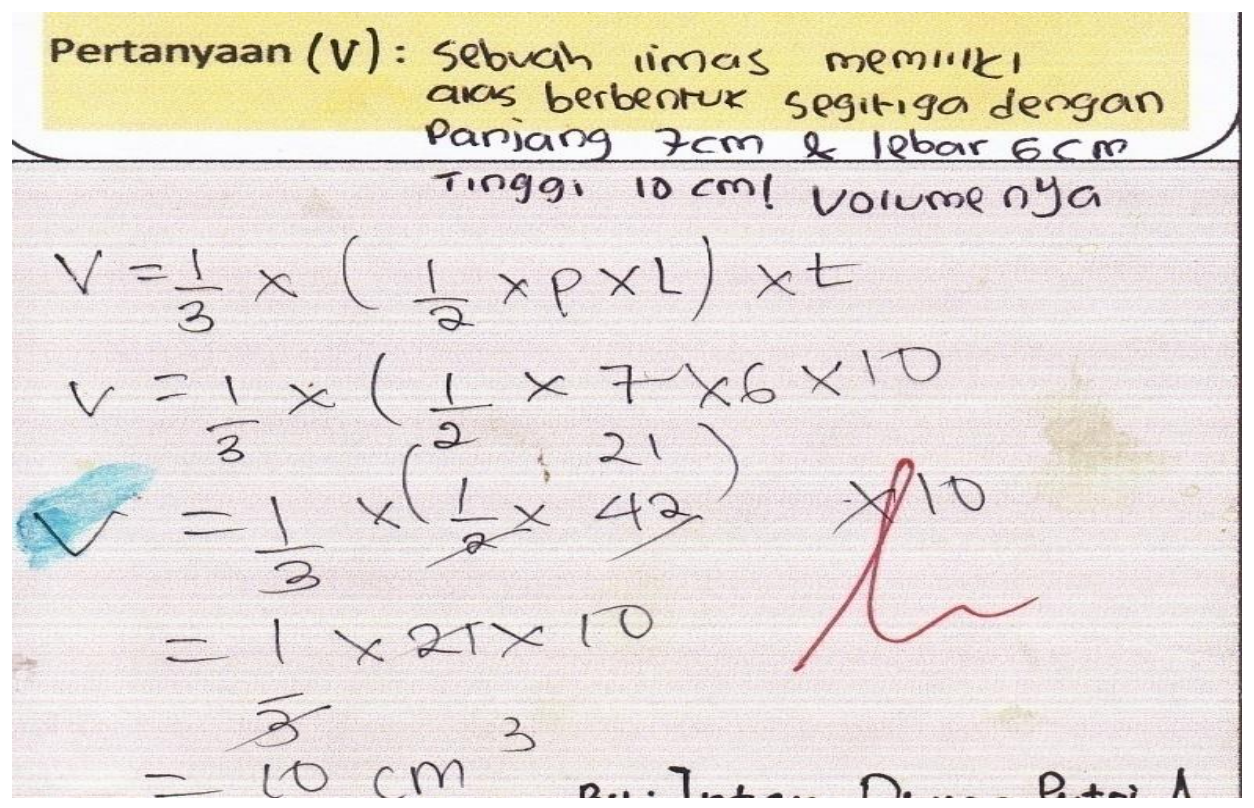

Gambar 4. Contoh hasil jawaban siswa pertemuan IV 
Penelitian yang dilakukan selama 4 pertemuan dengan menggunakan Strategi pembelajaran aktif tipe Everyone is a teacher Here ini membuat siswa mampu bertanya melalui kartu indeks dan berdiskusi dengan teman sekelompoknya untuk menjawab pertanyaan tersebut. Selain itu, siswa mampu menjelaskan materi yang dipelajari kepada teman sekelasnya. Siswa juga mampu menjawab soal-soal dan saling bekerja sama dengan anggota kelompok dalam menyelesaikan soal tersebut. Siswa yang malas menjadi terpacu untuk mengerjakan tugas dalam kelompok karena salah satu dari anggota kelompok akan dipilih secara acak untuk menjelaskan materi di depan kelas.

Pertemuan pertama sampai keempat pada kelas kontrol, pembelajaran berlangsung secara konvensional. Guru memberikan latihan soal untuk dikerjakan masing-masing dan boleh didiskusikan dengan teman sekelompok. Kemudian guru memberikan kesempatan kepada siswa utuk menjawab latihan dan menuliskannya didepan kelas. Pada pertemuan pertama hanya beberapa siswa yang mau mengerjakan latihan yang diberikan oleh guru, sementara siswa yang lain hanya menyalin jawaban temannya. Beberapa siswa malas mengerjakan latihan yang diberikan oleh guru dengan alasan tidak mengerti dengan materi yang dijelaskan guru.

Pertemuan kedua, ketiga dan keempat guru memberikan motivasi kepada siswa kelas kontrol agar tidak malas lagi mengerjakan latihan yang diberikan guru. Berdasarkan pengamatan selama penelitian, terlihat siswa pada kelas eksperimen lebih aktif dalam belajar. Hal ini disebabkan dalam proses pembelajaran siswa dilibatkan dan saling bekerjasama dalam diskusi kelompok. Pada diskusi kelompok semua anggota kelompok harus paham dengan materi yang dipelajari, karena setiap anggota kelompok akan dipilih secara acak untuk mempresentasikan hasil diskusi.

Tes akhir dilaksanakan pada kelas eksperimen dan kelas kontrol. Siswa yang mengikuti tes akhir sebanyak 34 orang pada kelas eksperimen dan 29 orang pada kelas kontrol. Gambaran hasil tes akhir siswa pada kelas eksperimen dan kelas kontrol dapat dilihat dari lembar jawaban siswa yang berkemampuan tinggi dan rendah. Bentuk lembar jawaban tes akhir siswa pada kelas eksperimen dan kelas kontrol dengan berkemampuan tinggi dapat dilihat pada Gambar 5 dan Gambar 6.

Gambar 5 memperlihatkan bahwa siswa sudah mampu menguasai materi selama proses pembelajaran 4 kali pertemuan prisma dan limas Siswa mampu mengaplikasikan konsep-konsep luas dan volume dengan benar sesuai bentuk soal dan menyelesaikan soal tes akhir dengan baik dan benar. Namun pada hasil tes siswa ini ada sedikit kekurangan dalam menuliskan kesimpulan akhir.

Gambar 6 memperlihatkan bahwa siswa ini juga mampu menguasai materi tentang prisma dan limas selama proses pemabelajaran selama 4 kali pertemuan, tetapi siswa ini kurang mampu mengaplikasikan konsep-konsep luas dan volume dengan benar sesuai bentuk soal.

Contoh lembar jawaban tes akhir siswa pada kelas eksperimen dan kelas kontrol dengan berkemampuan sedang dapat dilihat pada Gambar 7 dan Gambar 8.

Berdasarkan Gambar 7 terlihat bahwa siswa mampu menguasai materi dan mampu menjawab soal dengan baik, tetapi masih ada sedikit kesalahan dalam mengalikan seperti soal no 4 menentukan volume limas. 
Berdasarkan Gambar 8 terlihat bahwa siswa mampu menguasai materi dan mampu menyelesaikan soal tes akhir, namun masih ada kekurangan dalam mensubtitusikan sehingga hasil akhir soal tersebut tidak didapatkan dari soal no 4 .

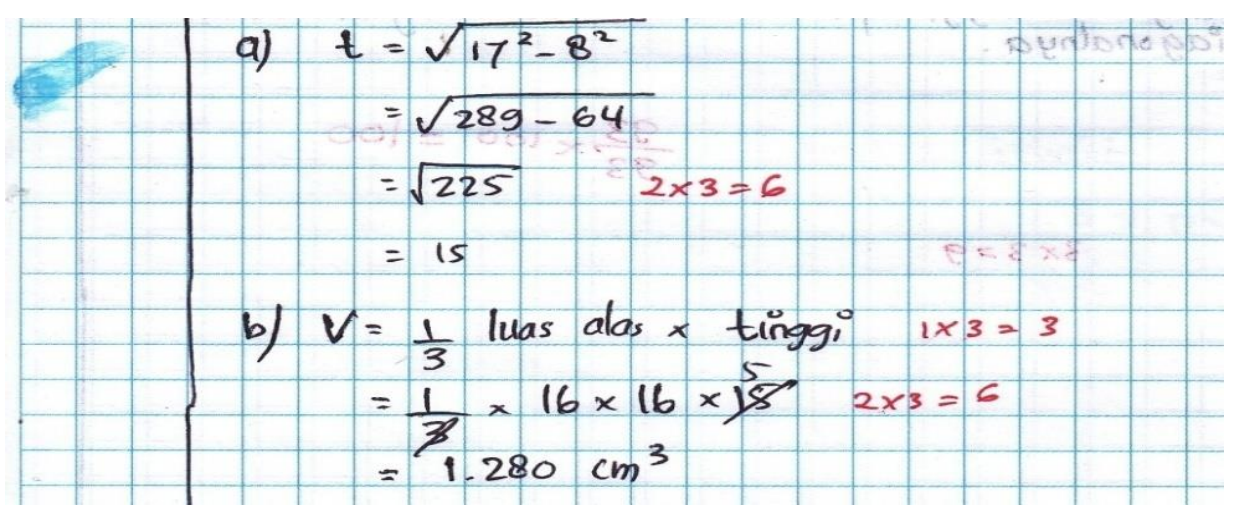

Gambar 5. Contoh hasil tes akhir siswa berkemampuan tinggi kelas eksperimen

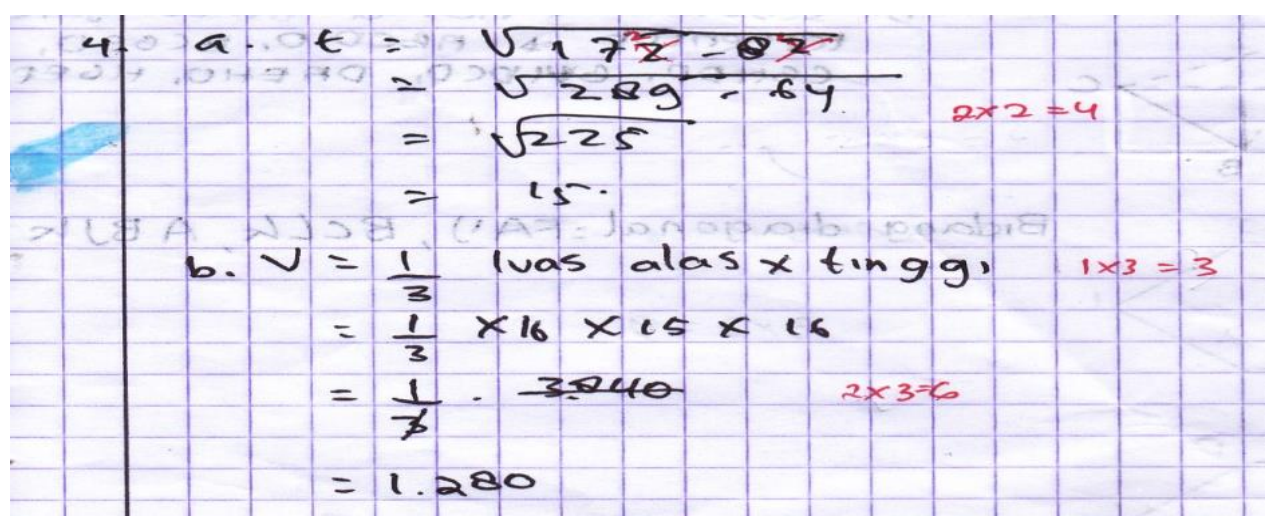

Gambar 6. Contoh hasil tes akhir siswa berkemampuan tinggi Kelas kontrol

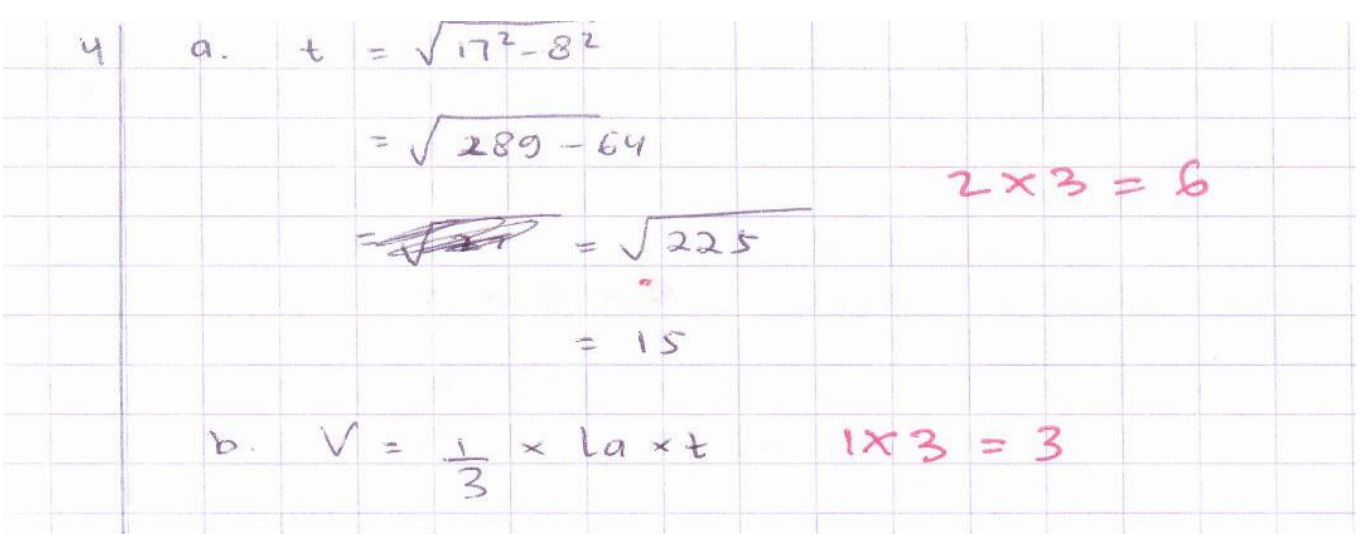

Gambar 7. Contoh hasil tes akhir siswa berkemampuan sedang Kelas kontrol 


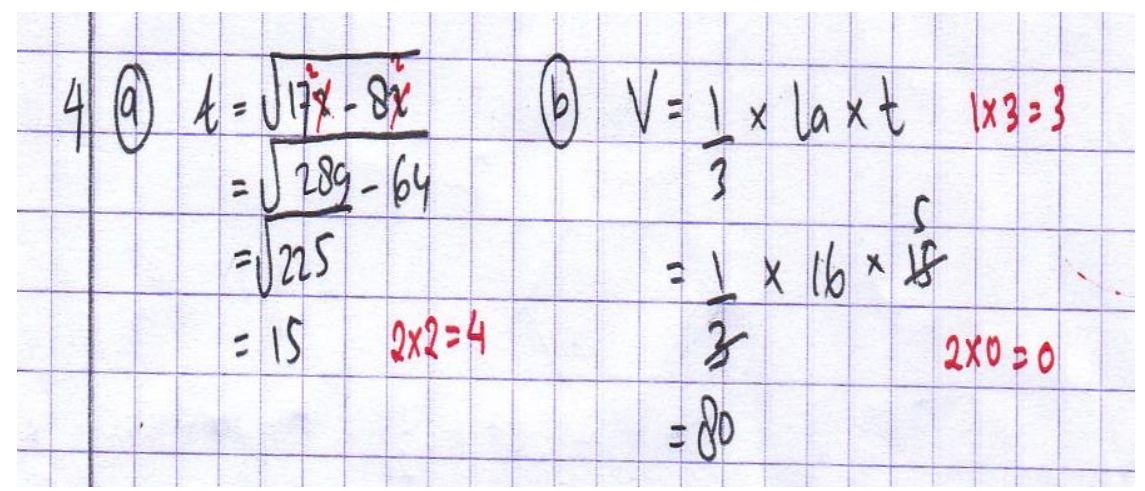

Gambar 8. Contoh hasil tes akhir siswa berkemampuan rendah kelas eksperimen

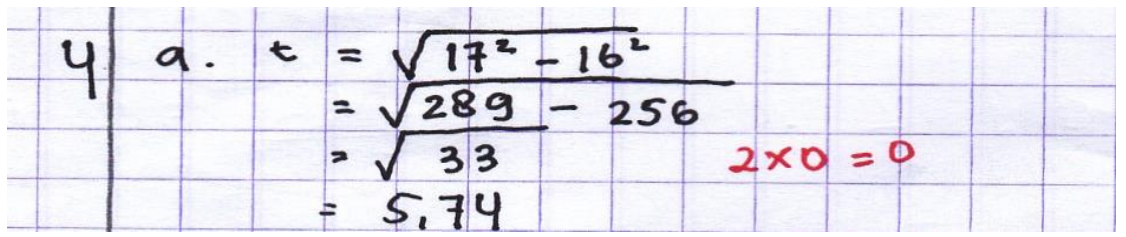

Gambar 9. Contoh hasil tes akhir siswa berkemampuan rendah kelas kontrol

Gambar 8 dan 9 memperlihatkan bahwa siswa masih kurang menguasai materi dalam mengaplikasikan konsepkonsep prisma dan limas terhadap bentuk soal-soal.Siswa kurang mampu menjawab dengan benar seperti soal no 4.

\section{PENUTUP}

Berdasarkan hasil penelitian dan pembahasan, dapat disimpulkan bahwa pemahaman ruang siswa dengan penerapan strategi pembelajaran Aktif tipe Everyone is a Teacher Here lebih baik dari pada pemahaman ruang siswa yang menerapkan pembelajaran konvensional.

\section{UCAPAN TERIMA KASIH}

Terbitnya tulisan ini tidak terlepas dari bantuan berbagai pihak, untuk itu penulis ucapkan terima kasih kepada UP3M STKIP PGRI Sumatera Barat dan pengelola jurnal Pelangi yang telah memberikan saran dan revisi dalam penulisan artikel ini.

\section{DAFTAR PUSTAKA}

Arikunto, Suharsimi.2010. Dasar-Dasar Evaluasi Pendidikan. Jakarta: Bumi Aksara.

Hamalik, Oemar. 2009. Kurikulum dan Pembelajaran. Jakarta: PT. Bumi Aksara.

Lie, Anita. (2010). Cooperative Learning. Jakarta : Grasindo.

Sardjana. 2008. Geometri Ruang. Jakarta: Universitas Terbuka.

Silberman, Mel. (2014). Active learning 101 Strategi Pembelajaran Aktif. Yogyakarta: Pustaka Insan Madani.

Sudjana. (2005). Metoda Statistika. Bandung: PT. Tarsito. 